\title{
Readymade Garments Sector and Covid-19 in Bangladesh
}

\author{
1. Md. Lutfor Rahman Shimanta, Student, Faculty of Agricultural Economics and Business \\ Studies, Sylhet Agricultural University. E-mail: Irshimanta@gmail.com \\ 2. Hridoy Gope, Student, Faculty of Agricultural Economics and Business Studies, Sylhet \\ Agricultural University. E-mail: hridoygope@gmail.com
}

\section{Israt Jahan Sumaiya, Student, Faculty of Agriculture, Sylhet Agricultural University. E-mail: isratjahan9826@gmail.com}

\begin{abstract}
:
The outbreak of Corona Virus effected negatively on the world's economy which has already touched the maximum sectors. Readymade garments sector has the large contribution in Bangladesh's economy. For increasing the locked down period, it is hitting badly by stopping production and cancellation of orders with some issues. This paper will represent the brief scenario and impacts of garments sector in recent days and the economy status of Bangladesh for the pandemic. The study is based on secondary data, collected from different authentic journals and web portals etc. Bangladesh's garments earnings mostly depended on export but on these days, the buyers are cancelling their orders and the factories are being failed to give payments to the worker, some are being shut down also. As the duration of locked down is increasing, there is a huge chance to get unemployed and Bangladesh can be faced an undisciplined condition in near future. BGMEA and BKMEA are taking necessary steps to support the worker. Ensuring health security, the authorities are trying to reopen the factories limitedly to meet up the immediate needs. The government has taken the situation on most priority and introduce some improvement packages to run the economy smoothly and reduce the losses of the country for the pandemic.
\end{abstract}

Keywords: Readymade Garments, Covid-19, Worker, Employment, Economy, Bangladesh. 


\section{Introduction:}

Severe Acute Respiratory Syndrome in short SARS virus is a virus of the family of Coronaviridae generally affects the animal body, but in some special cases it can affect the human body (WHOa 2020, Adhikari et.al. 2020). The virus is now popularly known as corona virus which attacks in respiratory organ of the body. Coronavirus is a large family of viruses which cause lethal diseases such as Middle East Respiratory Syndrome (MERS) and Severe Acute Respiratory Syndrome (SARS), just from regular cold (Corona Info, 2020). Recently, it has spread across the globe and affected more than 7.8 million people and the deaths are more than 0.43 million which is increasing day by day where in Bangladesh there are 65412 active cases and deaths are 1139 and the tests are 2976 per million till 13 June 2020 (worldometer.info). It was first spread from the states of Wuhan in China. After that very soon it attacks globally and now Italy, Iran, France, China, USA, Brazil, United Kingdom, Russia, Turkey and about 210 countries are affected with corona virus (Statista, 2020). Generally, the virus affected normally on the lower part of the respiratory tracts with the symptoms of pneumonia (Uddin et. al. 2020). The corona virus is generally transmitted through very close (1ft. to $6 \mathrm{ft}$.) body contact or by small respiratory droplets produced during coughing, sneezing and even in talking (CDCa 2020, WHOb 2020, WHOd 2020). Almost 100,000 people are being affected every day, for which Covid-19 has already formed as an epidemic. However, a vaccine for coronavirus is yet to discovered and it has become an issue of frustration among people (WHO, 2020). Coronavirus has put a negative effect on world economy, just like it has worsened the normal lives of people (Duffin, E, 2020). International Monetary Fund (IMF) says that the global economy will shrink by 3\% this year (BBC, 2020). The growth rate will decrease from $2.7 \%$ to $1.2 \%$ (IMF, 2020). In pursuance of, UNDESA the growth rate can collapse to $0.9 \%$ at the end of 2020, which Oxford economics presumed 2.8\% (UN, 2020; Oxford, 2020). As per OECD the global growth rate can show a decrement from $0.5 \%$ to $1.5 \%$ (BBC, 2020). South-Asian countries have been affected to a great extent. In Bangladesh, the number of affected corona virus patient is increasing day by day by breaking the record of previous day. As the garment's factory is a place where people have to work in very short place, it has the huge chance to spread corona virus. For that reason, most of the garments are shut down, so production has stopped for a longer time.

The garments sector popularly known as the Ready-Made Garments (RMG) is the largest industrial sector in Bangladesh which contributes most in GDP, foreign exchange, employment generation 
etc. It generally creates generation of about 4.4 million people where mostly are women which are from the disadvantaged part of the society most. This sector is the second largest RMG exporters next to China (Hossain et. al., 2019). Bangladesh has the inefficiency of producing cotton in domestic, that's why it has the huge demand of Chinese cotton as for easy access with fair price. Before the independence of Bangladesh Garments industry established but it was spread after the independence. On starting position the worth by Bangladesh was only USD\$ 69000 which was exported by Reaz Garments to USA in 1978 (Bhattacharya et. al. 2002). The repeated trial of RMG entrepreneurs, status and help of domestic economy with global market opportunities made the garments sector strong in the developing world. To reduce and fill up the jute markets falls in forex earnings, RMG tried to replace it then (Mia et. al. 2019). About more than 30 million people directly or indirectly involved with garments activities in the country (Hossain et. al., 2019). During the financial year of 2013-14, Bangladesh has earned about US\$24.5 billion from Garments sector which was the $80 \%$ of overall export earnings. To achieve the vision 2021 , with the improvement of technological, social and economic development, it has set the mission to earn about US\$ 50 billion by next 5 years (ActionAid Bangladesh, 2016). The background history of success for the sector is the lower cost of labour and available labour in the country by which employment problem has also been reduced.

But during the pandemic, this sector is hampering day by day. Coronavirus pandemic has created a negative impact on global garments supply chain. Global renowned traders and retailers are supposed to cancel their orders because of imposing government restrictions where already a million of workers have already lost their jobs and some are temporarily jobless which is increasing day by day (CARE, 2020). Research from over 3300 buyer and supplier over the 118 countries shows, coronavirus has hit the production of garments industry brutally where only $38 \%$ respondents concluded their customers are supportive with them (Ethical trade, 2020; Clean Clothes Campaign 2020). On the first four month of 2020, the global trade has been dropped by $3 \%$ and expecting trade volume will decrease between $13 \%$ and $32 \%$ in this year and global growth will go in negatively by 3\% due to Covid-19 (Teodoro et. al., 2020; WTO, 2020; IMF, 2020). In the last month (February, 2020), cotton yarn has lost 2 to $3 \%$ trade and synthetic yarn also lost 4 to 5\% (Business Standard, 2020). There are about 43 million people are at job risk in last two months for the pandemic (Cnet, 2020). The Figure 1 shows the number of workers at losing jobs (in million) in the world due to corona pandemic. 


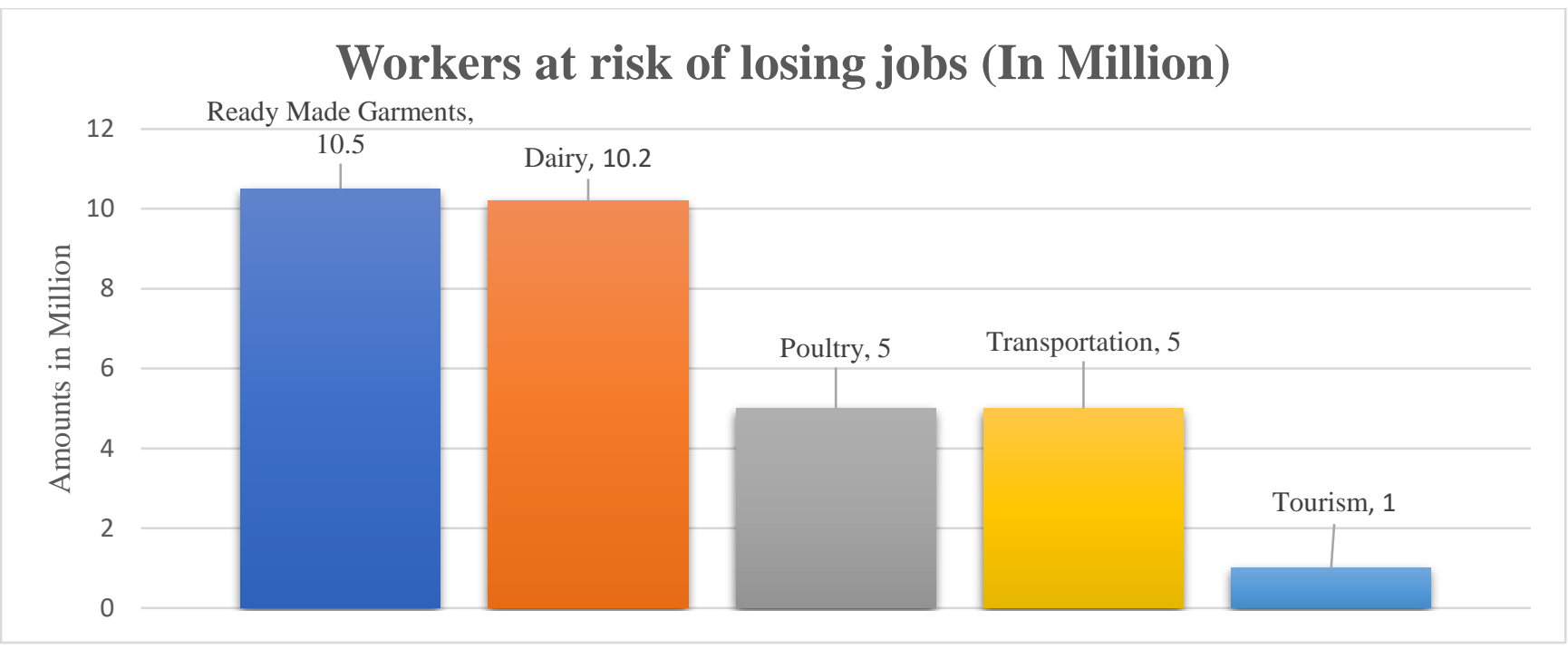

Figure 1: Workers at risk of losing their jobs in the world at different sector (In Million)

(Source: Databd.co)

A large number of people are involved directly or indirectly in Garments sector where they are in the high risk of losing their jobs in plenty. In dairy, tourism, poultry, transportation has the same effect also. Recently, the orders are being cancelled, major brands are at risk of returning their investment, different factories are closing their doors, millions of jobs are in threated and driving the economy (Aljazeera. 2020). As there is no vaccine till now (13 June 2020), Govt. are taking some effective measures and policies to run the economy well and can be safe from depression period due to Covid-19 hit.

\section{Research Objectives:}

This paper aims at realizing the scenario of Covid-19 hit at the readymade garments sector in Bangladesh followed by the initiatives taken by different organization to reduce the loss and the situation with economic impact of Bangladesh for the pandemic.

\section{Methods and Materials:}

Covid-19 situation is updating every day. So, the study is based on secondary information. Information is collected from different authentic journals, newspapers, web portals, policy experts, press releases, media reports and so on. The study is designed to give a brief the scenario of garments sector in Bangladesh affected by the pandemic. The internet is a major source for data 
collection and review of literature. There is no quantitative but qualitative prediction is shown based on the data collected.

\section{Results and Discussion:}

\section{Covid-19 and Garments sector in Bangladesh:}

Covid-19 is now not only a global health crisis, but also the deep impact of economic crisis and labor market (Mckeever, 2020). The pandemic has already made shut down all kind of economic sectors like public transportation, airlines, luxury goods sector etc. (Macksoud et al. 2020, Muro et. al, 2020). Though still now people in Bangladesh don't affected roughly as Italy or America but the numbers are still increasing which turned to shut down most of the factories (Sen et. al., 2020). On the other hand, different buyers and importers are cancelling their orders. The last year apparel export on the same month is US\$ 26.24 billion (4.8\%) more than this year and only in February, the export has decreased US\$3.32 billion than last year (Perera, 2020). An interview concludes that if this situation continues for a longer time it can affect global supply and demand, where loss revenue could reach US\$4 billion (Amit, S. 2020). Export Promotion Bureau said, this year, Garments earnings fell by $14.08 \%$, Woven garments earnings by $14.31 \%$ and Knitwear exports by $13.85 \%$ during July-April period of FY 20 than last year (The Financial Express, 2020). In the contribution of economy in Bangladesh, Garments industry remains the largest exporting industry which increased phenomenal growth during the last two decades (Mia et. al. 2020). The garments sector has provided employment opportunities to workers from the rural areas that previously did not have any to be the part of formal workforce. Eventually, it helps to poverty alleviation, women empowerment and social development. An indirect locked down was imposed first on 26 March 2020 and extended it 6 times till 30 May 2020 considering the corona pandemic situation in Bangladesh. Schools, Colleges and factories as well as transport, industrial and agricultural facility were shut down (AA News, 2020).

The below Figure 2 shows the closures of workplace, public events cancellation, income support and public transport closure. 


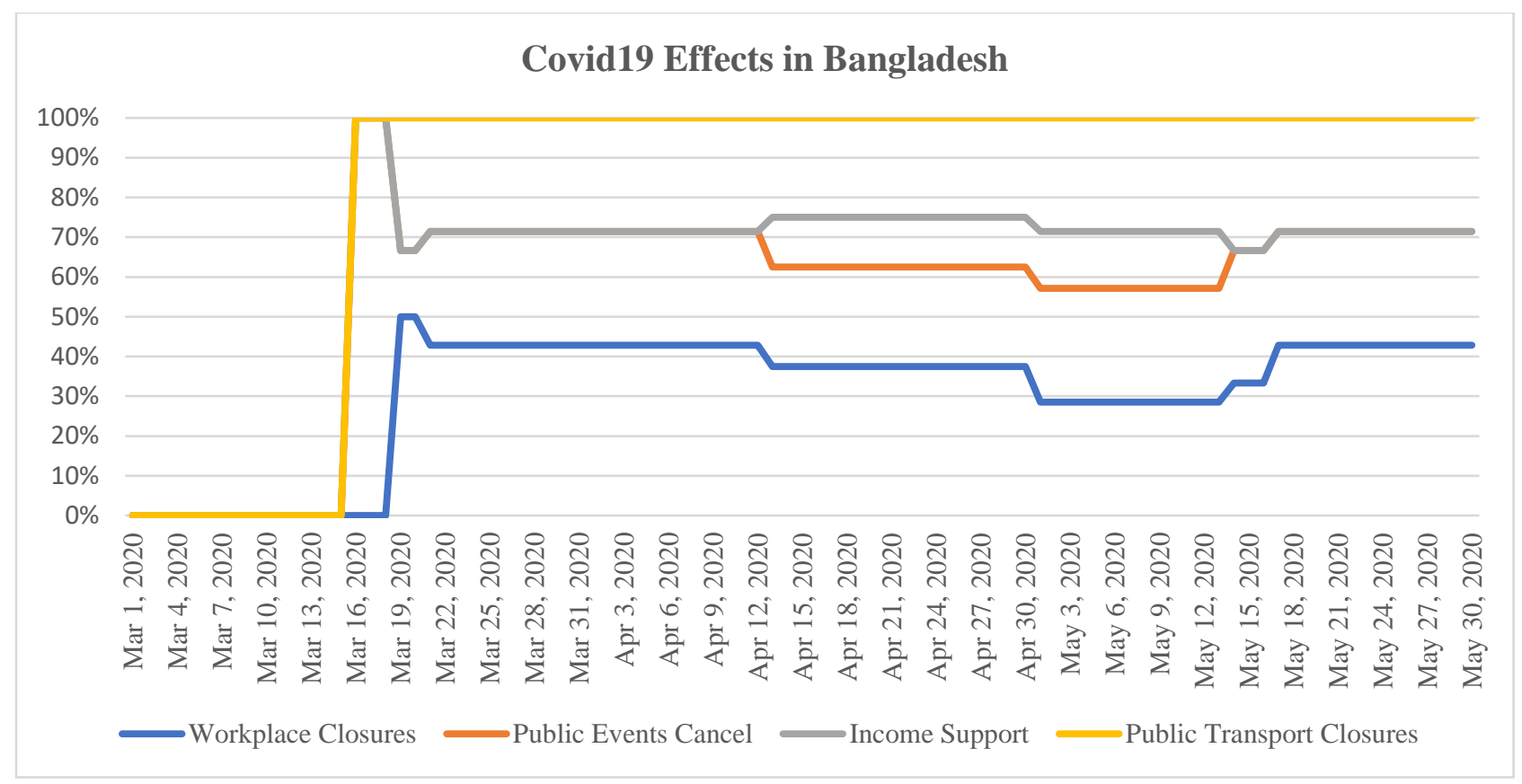

Figure 2: Situation of some sectors in Bangladesh for Covid-19

(Source: Our world in data, 2020)

On this figure 2, from March 16 the public transports are totally closed till May 30, where millions of people become jobless. Public events and workplaces have been closed for much time, only some govt. workplaces were opened like defense, hospitals, emergencies etc.

Bangladesh Apparel factories accounted for some 84\% of the total country's export but for the pandemic, major buyers from different countries like Topshop, Asda, Urban outfitters, Sports direct, New look, Peacocks and some bigger companies had cancelled their orders on March and April which worth can be about US\$ 3.4 billion (The Guardian, 2020). On the contrary, the workers are not getting paid. The STAR (Sustainable Textile of Asian Region) has tried to organize the associations of Bangladesh, Cambodia, Myanmar., Pakistan, China and Vietnam who produce fashion goods released a statement on this issue (STAR, 2020). Failing to recover the payment and loses of orders, the Management team of Tanaz fashion in Bangladesh has decided to shut down their factory (Dhaka Tribune, 2020). RMG Sustainability Council (RSC) conducted more than 1600 garments factories to eventually recover the workplace safety programs and mitigate the loss due to Covid-19 (The Financial Express, 2020). BGMEA decided to repair manufacturing units with $30 \%$ of the workforce advising to ask only the worker living near their respective 
factories to join. But on that spot more than 50\% are working and 70-90\% of them are violating the Covid-19 guidelines, BGMEA inspection team reported (The Financial Express, 2020). On this financial year, on the first 10 months (July-19 to April-20), the profit goes negatively 14\% which is the lowest in the last 5 years. In only in the month May 2020, the profit goes negatively $55.7 \%$. From March to June, US\$ 3.18 billion with 982 million pieces orders has been canceled and 2.28 million workers have been affected in Bangladesh whose jobs are in threatened. According to Meckengi, the revenue of Bangladesh from garments sector will decrease about US $\$ 10$ billion which means 30\% for the hit of Covid-19 in 2020 (BGMEA, 2020).

According to International Monetary Fund (IMF), the real GDP growth of Bangladesh is projected to decelerate to $2.0 \%$ in FY 2019-2020 driven by falling Readymade Garments exports, lower private investment growth and wider disruptions due to Covid-19 (Holy, 2020).

\section{Bangladeshi economy status and Covid-19:}

Still there is no vaccine has discovered, it will be needed to protect the virus by implementing some measures like locked down, hand sanitizing, musk using and so on. Longer duration of locked down will hamper more for the economy.

\section{Number of total Cases in Bangladesh}

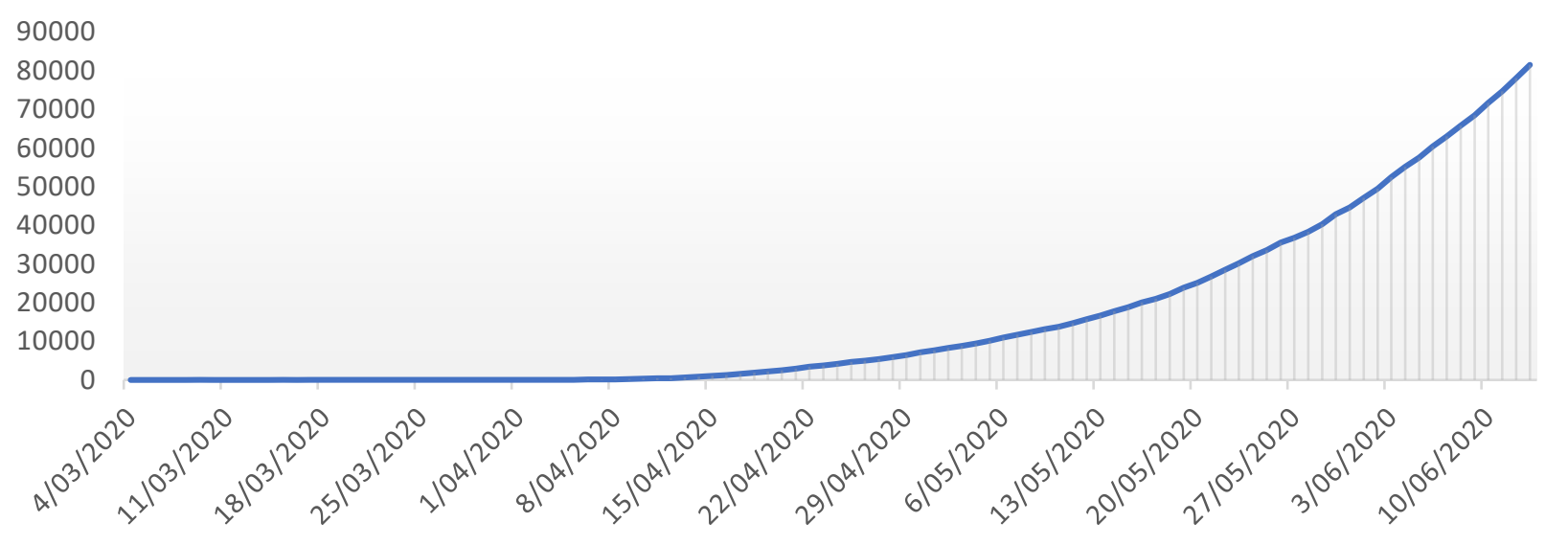

Figure 3: Number of total cases by Covid19 in Bangladesh.

(Source: Corona.gov.bd)

On figure 3, it revealed that the total number of positive cases increases in Bangladesh day by day and the highest number of affected is on $12^{\text {th }}$ June 2020 which is 3471 a day. 


\section{Number of Total deaths in Bangladesh}

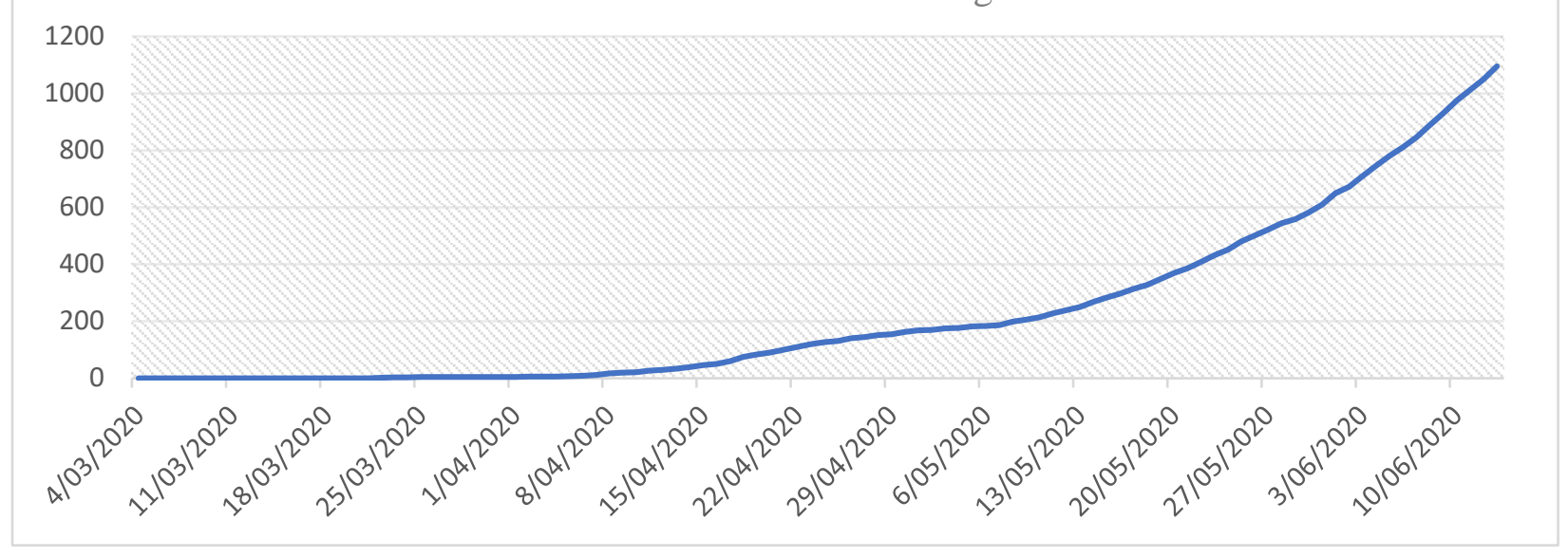

Figure 4: Number of total deaths by Covid19 in Bangladesh

(Source: worldometers.info/coronavirus)

On figure 4, the highest recorded death is on $12^{\text {th }}$ June 2020 , which is 46 a day and on 11 June it crosses 1000 where the cure is also upward. To flattening the curve, the govt. is trying to give support to the all classes of people and releases some packages also with some daily life facility. To take the number as low, govt. is extending the locked down on different methods.

World Bank data shows that there is only $15 \%$ people can earn more than Tk.500 (US\$ 5.90) a day and can meet up their livings. For extended locked down, Bangladesh might face worst humanitarian crisis (Textile Today, 2020). Inter Press Service reported, the income of the poor people has dropped by $80 \%$ between March and April where sufferings of 7 million slum dwellers is increasing drastically because of price hike of consumer goods (The independent, 2020; IPS News, 2020). As an agricultural country, there has a huge demand of seasonal worker in the crop field which is not meeting up these days and due to locked down, crops are damaging and farmers are not getting their fair price which hampers our total national income. About 20\% of Bangladeshi people depend on poultry and livestock directly or indirectly, to stimulate these sector government has initiated to give US\$589 million to the farmers (Islam et. al, 2020). According to Mr. Abdus Salam Aref, former Secretary general of the association of Travel Agents of Bangladesh, on March $1^{\text {st }}$ week, outbound and inbound passengers had fallen respectively $70-80 \%$ and $35-40 \%$ and expected to fall inbound passengers by 70-80\% at the end of March which will affect the tourism and aviation sector at large (Amit, S. 2020). On this pandemic, people are becoming jobless, 
stressful, suffering anxiety and falling in depression. Every day, the number of unemployed members is increasing where the rate is $4.4 \%$ with the population (The Daily Jugantor, 2019) and about of all the population $70 \%$ of them are live from hand to mouth where due to Covid-19 for poor Bangladeshi people, per capita income dropped by $82 \%$ in early April to US $\$ 0.32$ which was US\$1.30 in February (Kamruzzaman et. al, 2020). On 9 March 2020, Dhaka stock exchange faced the biggest loss of one day during the last 6/7 years which was 279.32 points $(6.5 \%)$ (The independent, 2020). As the pandemic was widely spread in China, different industry cannot supply the raw materials to ships on time which has affected our local industry also, because most raw materials are purchased from China. Wuhan is renowned for motorcycle accessories and is the first province to spread, Bangladeshi importers now need to wait or think to be alternative (Iraj, S. 2020). In the starting of March, it is estimated that 894,930 jobs will be lost wiping US\$ 3.02 billion off the US\$ 300 billion plus economy and due to less supply of raw materials, it will hurt the export sector and overall trade (The Diplomat, 2020). The Economist Intelligence Unit (EIU) are doubting to decrease the GDP by $4 \%$ in the next year. After the pandemic, it needs to be faced the unemployment, liquidity crisis, negative exports position, food crisis, closed of the industries and many others. To face and reduce the crisis, Bangladesh government has facilitated some helping packages in different sectors also (The Business Standard, 2020).

\section{Conclusion:}

Corona Virus pandemic is now a great concern for all over the world. It has already crashed the world economy and also affected in various sectors. It will be needed some years to come back to the previous normal situation for the countries. Maintaining proper health measures and consciousness, the outbreak effect can be reduced. The government needs to budget more in research and development sector to invent the vaccine and be alert for upcoming threat like this. The health sector should also be reorganized with improved facility and better technology which we can afford. To face any unexpected event like corona, government should make a special wing for Human Virome. The garments sector contributes the most in export earnings, so, it can turn out the economy of Bangladesh now. Though, some companies are returning their due recently, the amount of cancellation of orders are so high where factories cannot give the payments of the employer and they are losing their jobs which will increase our unemployment rate day by day. Many families are facing the trouble to survive on this situation who mainly depends on this sector. 
To raise the economy line, Bangladesh government, BGMEA and BKMEA with some industries are trying to fulfill the basic needs of the workers and introduce subsidy for different issues. The garments workers need to be paid as soon as possible considering their economic condition. After ensuring the health security, government should reopen the factories to continue the production and the authorities should make contact with buyer and supplier to regain the market loss of the sector immediately.

\section{Authors Contribution:}

The study is conducted together by all authors. MLRS gave the idea, designed the study and made a first draft of the study. HG and IJS studied the literature review and crossed the data. IJS collected quantitative data through valid websites and made graphical presentation. The responsibility will go to the all authors for any mistakes and promised to correct in the next edition. All authors have approved the present final manuscript.

\section{References:}

1. AA News (2020). Covid-19: Bangladesh extends locked down until May 30. Archived from the original on 14 May 2020. Accessed 26 May 2020 at: https://www.aa.com.tr/en/asia-pacific/covid-19-bangladesh-extends-locked-down-untillmay-30/184012

2. ActionAid Bangladesh. (2016). Three years Post Rana Plaza: Changes in the RMG Sector. Archived from the original on 15 April 2020. Accessed 26 April 2020 at: https://actionaidbd.org>media

3. Adhikari S. P., Meng, S., Wu, Y., Mao, Y., Ye, R., Wang, Q., Sun, C., Sylvia,S., Scott Rozelle,S., Raat, H., and Zhou, H. (2020). Epidemiology, causes, clinical manifestation and diagnosis, prevention and control of coronavirus disease (COVID-19) during the early outbreak period: a scoping review, Infectious Diseases of Poverty, 9:29. Accessed 23 April 2020.

4. Aljazeera (2020). Corona Virus Pandemics threatens Bangladesh Garment Industry. Archived from the original on 01 April 2020. Accessed 26 April 2020 at: https://www.aljazeera.com/news/2020/04/coronavirus-pandemic-threatens-bangladeshgarment-industry-20040115602704.html 
5. Amit, S. (2020). Long Read: Coronavirus and the Bangladesh economy: Navigating the global Covid-19 shutdown, London School of Economics. Archived from the original on 03 April 2020. Accessed 27 April 2020 at: blogs.lse.ac.uk, http://eprints.lse.ac.uk/104465

6. The Diplomet (2020). Will the pandemic derail Bangladesh's economic growth?. Archived from the original on 18 April 2020. Accessed 26 May 2020 at: http://thediplomat.com/2020/04/will-the-pandemic-derail-bangladshs-economic-growth

7. Bangladesh Garment Manufacturers and Exporters Association (BGMEA). (2019a). Trade information: Membership and employment. Accessed 26 April 2020 at: http://www.bgmea.com.bd/home/pages/tradeinformation

8. Battacherja, P., \& Hossian, M.S. (2017). Bright Future Awaits the RMG sector. The Independent, BD. Archived from the original on December 29, 2017. Accessed 28 April 2020 at: http://www.theindependentbd.com/arcprint/details/130159/2017-12-29

9. BBC (2020). Coronavirus: A visual guide to the economic impact. Accessed 14 May 2020 at: https://www.bbc.com/news/business-51706225

10. BBC (2020). US oil prices turn negative as demand dries up. Accessed 14 May 2020 at: https://www.bbc.com/news/business-52350082

11. Begum, M., Farid, M.S., Barua, S., Alam, M.J. (2020). COVID-19 and Bangladesh: SocioEconomic Analysis Towards the Future Correspondence. Preprints 2020, 2020040458 Accessed 29 April 2020. Manuscript at: doi: 10.20944/preprints202004. 0458.v1.

12. BGMEA (2020). Bangladesh Garment Manufacturers and Exporters Association (BGMEA), Press Release 06 June. Accessed 07 June 2020 at: http://www.bgmea.com.bd/

13. Bhattacharya, D., Rahman, M., Raihan, A. (2002). Contribution of the RMG Sector to the Bangladesh Economy. Accessed 28 April 2020 at: https://www.researchgate.net/publication/5224225

14. Bhuiyan, I., Sakib, N., Pakpour, A. H., Griffiths, M. D. and Mamun A. (2020). COVID19-related suicides in Bangladesh due to lockdown and economic factors: Case study evidence. International Journal of Mental Health and Addiction. Archived from the original on 15 May 2020. Manuscript at: http://doi.org/10.1007/s11469-020-00307-y

15. The Business Standard (2020). Cotton, yarn prices fall as coronavirus brings exports to China to a halt. Accessed 5 June 2020 at: https://www.business-standard.com/topic/cotton 
16. CARE (2020). What Impact Covid-19 In Global Garment Industry. Accessed 3 June 2020 at: https://www.careinternational.org.uk/what-impact-covid-19-global-garment-industry

17. CDCa (Centers for Disease Control and Prevention), Coronavirus Disease 2019 (COVID19) Transmission". Centers for Disease Control and Prevention. Accessed 27 April 2020

18. Clean Clothes Campaign (2020). Live blog: How the Corona virus affects garment workers in supply chain. Accessed 4 June 2020 at: https://cleanclothes.org/news/2020/live-blog-onhow-the-coronavirus-influences-workers-in-supply-chains

19. Cnet (2020). Dori Zinn, Coronavirus Unemployment: everything to know about how to apply, payments and more. Accessed 10 June 2020 at: https://www.cnet.com/personalfinance/coronavirus-unemploment-furlough-payments-applying-more/

20. Corona Info (2020). Worldwide Corona Virus Statistics Data. Accessed 15 May 2020 at: https://corona.gov.bd/banner/48

21. Coronavirus Update (Live) - Worldometer. www.worldometers.info. Accessed 28 May 2020

22. Daily Jugantor (2019). Bangladesh as second highest in unemployed graduates (In Bangla). Archived from the original on 23 April 2020. Accessed 26 May 2020 at: https://www.jugantor.com/todays-paper/economics/135236/

23. Dhaka Tribune (2020). RMG workers protest mass layoffs in Gazipur. Accessed 29 May 2020 at: https://www.dhakatribune.com/business/2020/06/01/rmg-workers-protest-masslayoffs-in-gazipur

24. Duffin, E. (2020). Impact of the coronavirus pandemic on the global economy - Statistics \& Facts. Accessed 15 May 2020 at: https:/www.statista.com/topics/6139/covid-19impact-on-the-global-economy/

25. Dutta, R. (2020). Covid -19: An impending threat to Bangladesh. Accessed 13 May 2020 at:https://www.researchgate.net/publication/339438905_COVID19_An_impending_threa t_for_Bangladesh_RMG

26. Ethical Trade (2020). Sedex number survey garments footwear and construction suffering biggest economic hit. Accessed 28 May 2020 at: https://www.ethicaltrade.org/blog/sedexmember-survey-garments-footwear-and-construction-suffering-biggest-economic-hitduring 
27. Fair Wear (2020). Covid-19 impact and responses: Bangladesh. Archived from the original on 13 April 2020, Accessed 13 May 2020 at: https://www.fairwear.org/covid-19dossier/covid-19-guidance-for-production-countries/covid-19-impact-and-responsesbangladesh

28. Fernandes, N. (2020). Economic effects of coronavirus outbreak (COVID-19) on the world economy. Accessed 14 May 2020 at: SSRN: https://ssrn.com/abstract=3557504 or http://dx.doi.org/10.2139/ssrn.3557504

29. IPS News (2020). Amid Covid-19 Hunger Fear Mounts in Bangladesh. Archived from the original on 29 April 2020. Accessed 21 May 2020 at: http://www.ipsnews.net/2020/04/amid-covid-19-hunger-fear-mounts-bangladesh/

30. Holy, I. J. (2020). Covid-19 in Bangladesh: A visual guide to the economic impact, Light castle analytical wing. Archived from the original on 29 April 2020. Accessed 29 May 2020 at: https://databd.co/stories/covid-19-in-bangladesh-a-visual-guide-to-theeconomicimpact-11064

31. Hossain, S. (2020). The business standard. The Economy of Bangladesh after Corona virus is over. Archived from the original on 02 April 2020. Accessed at: http://tbsnews.net/thought/economy-bangladesh-after-corona-virus-over-64021\%3famp

32. Hossain, S., Kabir, R., Latifee, E. H. (2019). Export Competitiveness of Bangladesh Readymade Garments Sector: Challenges and Prospects. International Journal of Research in Business and Social Science. Manuscript at: Vol 8 No 3, Special Issue, 2019. ISSN: 2147-4486. Manuscript at: https://doi.org/10.20525/ijrbs.v8i3.205. Accessed 27 April 2020 at: www.sfbnet.com/ojs; https://www.researchgate.net/publication/333015024

33. IEDCR (2020). Research Institute of Epidemiology, Disease Control and. "করোনা ইনফো ". corona.gov.bd. Accessed 27 April 2020

34. ILO (2020). COVID-19 and the world of work: Impact and policy responses. ILO Monitor 1st Edition. International Labour Organization. Accessed 14 May 2020 at: at https://www.ilo.org/wcmsp5/groups/public/---dgreports/dcomm/documents/briefingn ote/wcms_738753.pdf

35. IMF (2020). World Economic Outlook Database. Accessed 15 May 2020 at: https://www.imf.org/external/pubs/ft/weo/2019/02/weodata/index.aspx 
36. IMF (2020). World Economic Outlook. Accessed 4 June 2020 at: https://www.imf.org/en/Publications/WEO/Issues/2020/04/14/weo-april-2020

37. Independent News (2020). Daily essentials see price hikes amid COVID-19 lockdown. Archived from the original on 4 April 2020. Accessed 21 May 2020 at: http://theindiependentbd.com/home/business.

38. Independent News (2020). Dhaka stocks nosedive on coronavirus shock. Accessed 26 May 2020 at: http://theindiependentbd.com/home/printnews/240245

39. Iraj, S. (2020). Bangladeshi importers who import many products from that particular province will have to find alternative suppliers or wait. The Independent. Accessed 26 May 2020 at http://m.theindependentbd.com/home/printnews/236504

40. Islam, T., Talukder, A.K., Siddiqui, N. and Islam, T. (2020). Tackling the Pandemic COVID-19: the Bangladesh Perspective. Manuscript at: doi:10.20944/preprints202004. 0384.v

41. Kamruzzaman, M. (2020). Coronavirus: Poor income drops $80 \%$ in Bangladesh. Archived from the original on 23 April 2020. Accessed 26 May 2020 at: https://www.aa.com.tr/en/asia-pacific/coronavirus-poor-income-drops-80-inbangladesh/180883

42. Light Castle (2020). The effect of Covid-19 on Bangladesh's Apparel Industry: Light castle Analytics Wing. Archived from the original on 29 March 2020. Accessed 3 June 2020 at: https://www.lightcastlebd.com/insights/2020/03/29/the-effect-of-covid-19-onbangladeshs-apparel-industry

43. Macksoud, L., Schrag, S., Richards, R. E., \& Alberts, S. J. (2020). Covid-19 and its impact on the global economy, from Dentons website. Accessed 28 April 2020 at: https://www.dentons.com/en/insights/alerts/2020/march/11/covid-19-and-its-impact-onthe-global-economy

44. McKeever, V. (2020). CORONAVIRUS Nearly 25 million jobs could be lost globally due to the coronavirus, UN labor organization estimates. CNBC. Archived from the original on 19 March 2020. Accessed 27 April 2020 at: https://www.cnbc.com/2020/03/19/nearly-25million-jobs-could-be-lost-globally-due-to-the-coronavirus.html

45. Muro, M., Maxim, R. and Whiton, J. (2020). The robots are ready as the Covid19 recession spreads. Archived from the original on 24 March 2020. Accessed 28 April 2020 at: 
https://limc-cimt.ca/now-of-wok/muro-m-maxim-r-whiton-j-2020-march-24-the-robotsare-ready-as-the-covid19-recession-spreads-washington-dc-brookings-institution/

46. Our Source in Data (2020). Coronavirus pandemic- Country Comparisons by Max Roser. Accessed 10 June 2020 at: https://ourworldindata.org/coronavirus-country-comparisons

47. Oxford Economics (2020). Global Coronavirus Watch: Feeling the pain. Accessed 14 May 2020 at: http://resources.oxfordeconomics.com/coronavirus-watch-feeling-the-pain

48. Perera, W. (2020). Bangladesh government downplays COVID-19 threat as job losses mount. Accessed 14 May 2020 at: https:/www.wsws.org/en/articles/2020/03/16/bangm16.html

49. The Guardian (2020). Bangladesh garment factories reopen despite corona virus threat to workers. Archived from the original on 11 May 2020. Accessed 13 May 2020 at: https://www.theguardian.com/global development/2020/may/11/bangladesh-garmentfactories-reopen-despite-coronavirus-threat-to-workers

50. Rahman, S. (2020), Revisiting Empowerment: Rising Female Unemployment in the Bangladesh Garment Sector, Accessed 27 April 2020. Manuscript at: DOI: $10.1177 / 194277861801100203$

51. Sen, S., Antara, N., Susmita, S. and Chowdhury, S. (2020). The Unprecedented Pandemic "COVID-19" Effect on the Bangladesh Apparel Workers by shivering the Apparel Supply Chain. Accessed 28 May 2020 at: https://ssrn.com/abstract=3598542; https://www.researchgate.net/publication/341373757

52. Mia, S., Akter, M. (2019). Ready-Made Garments Sector of Bangladesh: Its Growth, Contribution and Challenges. Economics World, Jan.-Feb. 2019, Vol. 7, No. 1, 17-26. Accessed 26 April 2020. Manuscript at: doi: 10.17265/2328-7141/2019.01.004

53. Statista (2020). Covid-19 cases worldwide as of June 12, 2020 by country. Archived from the original on 12 June 2020. Accessed 13 June 2020 at: htps://www.statista.com/statistics/1043366/novel-corona-virus-2019ncov-casesworldwide-by-country/

54. STAR (2020). Joint statement on Responsible Purchasing Practices amid the COVID-19 Crisis. Archived from the original on 09 April 2020. Accessed 4 June 2020 at: http://www.asiatex.org/ennewss/393.html 
55. Teodoro, A. and Rodriguez, L. (2020). Textile and garment supply chains in times of COVID-19: challenges for developing countries. Archived from the original on 29 May 2020. Manuscript at: Article No. 53 [UNCTAD Transport and Trade Facilitation Newsletter No86 - Second Quarter 2020]. Accessed 3 June 2020 at: https://unctad.org/en/pages/newsdetails.aspx? OriginalVersionID=2380

56. Textile Today (2020). Bd might Face worst Humanitarian Crisis. Archived from the original on 22 April 2020. Accessed 9 June 2020 at: https://www.textiletoday.com.bd/bdmight-face-worst-humanitarian-crisis/

57. The Financial Express (2020). Export earnings witness 83.85pc negative growth in April. Archived from the original on 09 May 2020. Accessed 14 May 2020 at: https://thefinancialexpress.com.bd/economy/bangladesh/export-earnings-witness8385pcnegative-growth-in-april-15891927

58. The Financial Express (2020). Infections among RMG workers increasing as factories breaching health guidelines. Archived from the original on 2 May 2020. Accessed 25 May 2020 at: https://thefinancialexpress.com.bd/trade/infections-among-rmg-wokersincreasing-as-factories-breaching-health-guidelines-1588438626

59. The Financial express (2020). RSC takes over accord operations. Accessed 1 June 2020 at: https://thefinancialexpress.com.bd/trade/rsc-takes-over-accord-operations-1591003032

60. Uddin, J. and Illius, S. (2020). 4 RMG workers tested positive with Corona Virus. Archived from the original on 29 April 2020, Accessed 13 May 2020 at: https://tbsnews.net/coronavirus-chronicle/covid-19-bangladesh/4-rmg-workers-testedpositive-coronavirus-75151

61. Uddin, M. B., Hasan, M., Rashid, A.H.A., Ahsan, M. I., Imran, M. A. S., Ahmed. S. S. U., (2020). Novel Coronavirus (COVID-19): Molecular Evolutionary Analysis, Global Burden and Possible Threat to Bangladesh. Nature Research. *(preprint) Accessed 27 April 2020

62. UN (2020). World Economic Situation and Prospects: April 2020 Briefing, No. 136. Accessed $15 \quad$ May at: https://www.un.org/development/desa/dpad/publication/world-economic-situation-andprospects-april-2020-briefing-no-136/

63. WHO (2020). WHO Coronavirus Disease (COVID-19) Dashboard. Accessed 21 May 2020 at: https://covid19.who.int/ 
64. WHOa. (World Health Organization): Coronavirus disease (COVID-2019) situation reports.2020. Accessed 26 April 2020 at: https://www.who.int/emergencies/diseases/novel-coronavirus2019/situationreports/.

65. WHOb. (2020). Statement on the second meeting of the International Health Regulations (2005) Emergency Committee regarding the outbreak of novel coronavirus (2019-nCoV)". World Health Organization. 30 January 2020. Archived from the original on 31 January 2020. Accessed 27 April 2020

66. WHOc- (2020). General's opening remarks at the media briefing on COVID-19-11 March 2020. World Health Organization. Accessed 27 April 2020

67. Worldometer (2020). COVID-19 CORONAVIRUS PANDEMIC. Accessed 17 May 2020 at: https://www.worldometers.info/coronavirus/

68. WTO (2020). Trade set to plunge as COVID-19 pandemic upends global economy. Accessed 15 May 2020 at: https://www.wto.org/english/news_e/pres20_e/pr855_e.htm

69. WTO (2020). Trade set to plunges COVID-19 pandemic upends global economy. Archived from the original on 08 April 2020. Accessed 4 June 2020 at: https://www.wto.org/english/news_e/pres20_e/pr855_e.htm 